\title{
Variation in $\beta$-Carotene and Total Carotenoid Content in Fruits of Capsicum
}

\author{
Marisa M. Wall ${ }^{1}$, Cynthia A. Waddell ${ }^{2}$, and Paul W. Bosland ${ }^{3}$ \\ Department of Agronomy and Horticulture, New Mexico State University, Las \\ Cruces, NM 88003-8003
}

Additional index words. peppers, pigments, human nutrition, vegetable breeding, chiles, Capsicum annuum, Capsicum chinense, Capsicum baccatum, Capsicum frutescens, Capsicum chacoense, Capsicum eximium

Abstract. The $\beta$-carotene and total carotenoid content of either fresh or dried tissue of fruits of a total of 57 cultivars of six Capsicum species were analyzed using high performance liquid chromatography (HPLC). $\beta$-Carotene levels in ripe fruit varied from 0 to 166 $\mu \mathrm{g} \cdot \mathrm{g}^{-1}$ fresh weight, and carotenoid levels were from $1 \mathrm{to} 896 \mu \mathrm{g} \cdot \mathrm{g}^{-1}$ in ripe fruit in 1996 . The range of values for $\beta$-carotene was similar in 1997 , but that for total carotenoids was wider (4 to $1173 \mu \mathrm{g} \cdot \mathrm{g}^{-1}$ fresh weight). Fresh fruit of the cultivars Greenleaf Tabasco, Pulla, Guajillo, NuMex Conquistador, Ring-O-Fire, and Thai Dragon contained greater amounts of $\beta$-carotene per $100 \mathrm{~g}$ fresh weight than the recommended dietary allowance (RDA) for vitamin A for the average adult. For dried Capsicum entries, New Mexican, aji, pasilla, and ancho types had the highest levels of $\beta$-carotene. In 1996, $\beta$-carotene levels among the dried Capsicum germplasm ranged from 2 to $739 \mu \mathrm{g} \cdot \mathrm{g}^{-1} \mathrm{dry}$ weight, and carotenoid levels from 111 to $6226 \mu \mathrm{g} \cdot \mathrm{g}^{-1}$. Values were higher in 1997 , ranging from 24 to $1198 \mu \mathrm{g} \cdot \mathrm{g}^{-1} \mathrm{dry}$ weight for $\beta$-carotene and from 187 to $10,121 \mu \mathrm{g} \cdot \mathrm{g}^{-1}$ for total carotenoids. A pasilla type $(C$. annuum $\mathrm{L}$.) had the highest total carotenoid content among the dried entries in both years.

Chiles (Capsicum sp.) are one of the oldest cultivated plants of the Americas, have been part of the human diet for thousands of years (Bosland, 1994), and are rich in vitamins A and C (Bureau and Bushway, 1986; Howard et al., 1994; Mejia et al., 1988; Simonne et al., 1997). Worldwide, vitamin A deficiency is the most common form of malnutrition after protein deficiency (World Bank, 1993). In parts of Asia, Africa, and Latin America, vitamin A deficiency occurs in millions of children (Sommer, 1989), and chiles could be an important source of provitamin A for the people of those regions. Chile production and consumption is increasing globally. Worldwide production is 11 million tons, with more than $48 \%$ produced in Asia, and per capita consumption is estimated at $10 \mathrm{~g}$ per day (Food and Agriculture Organization, 1995). In northern Mexico, consumption is $\approx 40 \mathrm{~g}$ per day (Valencia et al., 1983).

The yellow, orange, and red colors of Capsicum fruit originate from carotenoid pigments produced during ripening. Red chile and pa-

Received for publication 31 Mar. 2000. Accepted for publication 2 Oct. 2000. This research was supported by the Chile Improvement Project of the New Mexico State Univ. Agricultural Experiment Station. We thank Kathleen Dixon, Kelly Callahan, and Li Fang for excellent technical assistance. The cost of publishing this paper was defrayed in part by the payment of page charges. Under postal regulations, this paper therefore must be hereby marked advertisement solely to indicate this fact.

${ }^{1}$ Associate Professor. E-mail address: mawall@ nmsu.edu

${ }^{2}$ Research Assistant, Senior.

${ }^{3}$ Professor. prika carotenoids are used by the food industry as natural red colorants, but also have immense nutritional value as provitamin $\mathrm{A}$ and antioxidants. Evidence for antitumor activity of carotenoids has renewed interest in foods containing these compounds. The antioxidant properties of carotenoids appear to protect against heart disease (Kritchevsky, 1999) and cancer of the lungs, stomach, cervix, and throat (Byers and Perry, 1992; Machlin, 1995). Reports on the carotenoid content of chiles are primarily for bell, paprika, and jalapeño types (Bureau and Bushway, 1986; Howard et al., 1994; Levy et al., 1995, Mejia et al., 1988; Simonne et al., 1997). More than 30 carotenoids have been isolated from chiles (Gregory et al., 1987). The red capsanthin, capsorubin, and cryptocapsin pigments are valued mostly as natural colorants, whereas $\beta$ carotene, $\alpha$-carotene, $\gamma$-carotene and $\beta$-cryptoxanthin have provitamin A activity, with $\beta$ carotene having the highest activity.

Improvement of chiles (New Mexican type, C. annuum L.) for carotenoid and nutrient content is the goal of several breeding programs. To assist in identifying sources of high levels of carotenoids, 57 Capsicum cultivars from six species and 25 different fruit types were evaluated for variation in $\beta$-carotene and total carotenoid content. $\beta$-Carotene is the precursor for the predominant orange and red pigments in chiles, and genotypes with high concentrations of $\beta$-carotene proved to be richest in total carotenoid content. Therefore, $\beta$ carotene may be a selection criterion for developing highly colored chiles (Levy et al., 1995).

This information is useful not only for breeding highly colored paprika and chiles for the food industry, but also provides nutritional data for the range of fruit types within the Capsicum genus. Most vitamin A values reported in food composition tables are overestimated, because they are based on methodology in which $\beta$-carotene was not separated from other provitamin A pigments with lower activity (Haytowitz and Matthews, 1984). $\beta$ Carotene concentrations now can be accurately determined with HPLC (Bushway and Wilson, 1982).

\section{Materials and Methods}

$\beta$-Carotene and total carotenoid content were evaluated in different Capsicum fruit types and species using fresh fruit from 25 cultivars and dried fruit from 40 cultivars selected to represent a range of fruit types and uses (fresh or processed). Plots were established from transplants on a sandy loam soil at the Fabian Garcia Agricultural Science Center in Las Cruces, N.M., in 1996 and 1997. The beds were on 1-m centers and furrow-irrigated. Fertilizer $\left(112 \mathrm{~kg} \cdot \mathrm{ha}^{-1} \mathrm{P}\right.$ and $\left.168 \mathrm{~kg} \cdot \mathrm{ha}^{-1} \mathrm{~N}\right)$ was applied preplant as diammonium phosphate and in the irrigation water as urea and ammonium nitrate. Either fully ripened, succulent fruit or ripened, partially dry fruit were harvested for analysis. The number of fruit harvested per plant varied according to fruit type, and ranged from three for the larger bell, cubanelle, and pimiento types, to 150 for the smaller piquin and tepin types. Fruit were harvested separately from four plants and destemmed in the field. Fruit were deseeded for analysis of fresh fruit, except for the smallfruited tabasco, guajillo, Asian hot, serrano, and datil pod types, but not of dry fruit. Moisture content at harvest was determined from a subsample of each entry using an IR-100 moisture balance (Denver Instruments Co., Arvada, Colo.). Fruit harvested from individual plants were kept separate in the laboratory, and one sample from each accession was extracted and analyzed at the same time. There were four samples per accession.

Carotenoid extraction from fresh fruit samples was according to the methodology of Bureau and Bushway (1986). Chile samples were chopped into small pieces, and a $10 \mathrm{-g}$ subsample was immediately combined with 1 $\mathrm{g} \mathrm{MgCO}_{3}, 5 \mathrm{~g} \mathrm{Na}_{2} \mathrm{SO}_{4}$, and $125 \mathrm{~mL}$ tetrahydrofuran (THF) stabilized with $0.01 \%$ butylated hydroxytoluene (BHT). Each sample was homogenized with a Tekmar tissumizer (Cincinnati) for $5 \mathrm{~min}$ on medium speed. Samples were vacuum filtered (Whatman \#42), and the residue was re-extracted with an additional $125 \mathrm{~mL}$ THF. A $20-\mathrm{mL}$ portion of the sample was concentrated under nitrogen gas and stored at $-20{ }^{\circ} \mathrm{C}$ until HPLC analysis. Samples were resuspended in $0.4 \mathrm{~mL}$ THF and vortexed. Acetonitrile and methanol were added in equal amounts to a final volume of $4 \mathrm{~mL}$.

Prior to extraction of dry samples, whole fruit were dried in a $55^{\circ} \mathrm{C}$ oven and ground in a Wiley mill to pass through a 1-mm sieve. Carotenoids were extracted from dried samples by placing $0.2 \mathrm{~g}$ of powder in $50 \mathrm{~mL}$ stabilized THF. After $16 \mathrm{~h}$ in the dark, a $10-\mathrm{mL}$ aliquot 
was concentrated under nitrogen gas and stored at $-20{ }^{\circ} \mathrm{C}$. Samples were resuspended in 0.2 $\mathrm{mL}$ THF, and acetonitrile and methanol were added in equal amounts for a final volume of $4 \mathrm{~mL}$.

All samples were filtered through a nylon Magna $0.22-\mu \mathrm{m}$ filter into HPLC vials for injection. Analysis followed a modified carotenoid separation method of Ittah et al. (1993) and Levy et al. (1995) for nonsaponified pigments. A Hewlett-Packard 1090 series liquid chromatograph (Hewlett-Packard, Wilmington, Del.) fitted with a HewlettPackard 1040 series II photodiode array detection system was used. A gradient elution was used with an ODS Hypersil C-18 narrow-bore column $(5 \mu \mathrm{m}, 100 \times 2.1 \mathrm{~mm}$; HewlettPackard), starting with 39:53:8 acetonitrile:2propanol:water and ending with 60:40 acetonitrile:2-propanol after $20 \mathrm{~min}$. A 5-min postrun period with solvents reset to initial conditions was included. A $20-\mu \mathrm{L}$ sample was injected at a solvent flow rate of $0.5 \mathrm{~mL} \cdot \mathrm{min}^{-1}$. Column temperature was $40^{\circ} \mathrm{C}$. The range on the photodiode array detector was set at 380 $550 \mathrm{~nm}$, with maximum detection at $454 \mathrm{~nm}$.

The carotenoids were identified by their absorption spectra captured by the photodiode array detector, and HPLC retention times in comparison with authentic standards. Also, samples were spiked with standards to verify the identity of sample peaks with similar retention times. Capsanthin was obtained from Hoffman-La Roche (Basel, Switzerland) and $\beta$-carotene was obtained from Sigma Chemical Co. (St. Louis). Total carotenoids were quantified as capsanthin equivalents, and $\beta$ carotene by using an authentic standard. All standards were handled under low light on ice.
Standard solutions of $\beta$-carotene were prepared in $20 \mathrm{~mL}$ THF, and capsanthin standards in methanol:acetonitrile (1:1). Aliquots were diluted in methanol: acetonitrile $(1: 1)$ to provide standard concentrations ranging from 2 to $10 \mu \mathrm{g} \cdot \mathrm{L}^{-1}$. The detection limit was $0.1 \mu \mathrm{g} \cdot \mathrm{L}^{-1}$.

Data were analyzed using the generalized linear models procedure of SAS (SAS Institute, Cary, N.C.) for a randomized completeblock design, with samples blocked based on time of laboratory extraction and analysis.

\section{Results and Discussion}

Wide variation was observed among Capsicum entries for $\beta$-carotene $(P \leq 0.0001)$ and total carotenoids $(P \leq 0.0001)$ content of fresh and dry fruit for both years (Tables 1 and 2). Variation between years was nonsignificant for $\beta$-carotene $(P=0.40)$ or total carotenoids $(P=0.37)$ content in fresh fruit, but was significant for content of both in dry fruit $(P \leq$ 0.0001 and 0.001 for $\beta$-carotene and total carotenoids, respectively). In most cases, lower levels of $\beta$-carotene and total carotenoids were observed in 1996 than in 1997. The significant effect of years on dry, but not fresh, fruit pigment content can perhaps be explained by climatic differences. The weather at the time preceding and during fresh fruit ripening was similar in both years, with average daily temperatures of 26 to $27^{\circ} \mathrm{C}$ in July and August. However, in September, when fruit were beginning to dehydrate on the plants and accumulate pigments, the average daily temperatures were 22 and $25^{\circ} \mathrm{C}$ in 1996 and 1997 , respectively. In 1996, the cool September weather slowed ripening and was followed by an early freeze on 22 Oct. $\left(-2.2^{\circ} \mathrm{C}\right)$ and 23 Oct. $\left(-1.7^{\circ} \mathrm{C}\right)$, allowing less time for pigment accumulation and crop dry-down before the freeze. In 1997, a light frost occurred on 27 Oct. $\left(-0.6^{\circ} \mathrm{C}\right)$, but the first hard freeze did not occur until 30 Nov. $\left(-2.2^{\circ} \mathrm{C}\right)$. Fruit allowed to dry on the plant accumulate more pigments (Kanner et al., 1977; Palevitch et al., 1975), and fruit harvested after a freeze generally have less color in the dried product (Isidoro et al., 1990).

The interaction between years and cultivars was significant for all analyses $(P \leq$ 0.0001 ). This may have resulted from the large number of entries and the difference in magnitude between years. However, the performance of certain cultivars was inconsistent from 1996 to 1997 relative to that of the majority of entries. For example, dry fruit of 'Aji Brown' and 'Kalocsa', and fresh fruit of 'Greenleaf Tabasco', 'Habanero Red', 'Sante Fe Grande', and 'Biscayne' contained more carotenoids in 1996 than in 1997, whereas most of the remaining cultivars had higher carotenoid levels in 1997. Only one cultivar ('NuMex Conquistador') that was analyzed both as fresh and as dry fruit consistently had high carotenoid levels in all analyses for both years.

$\beta$-Carotene and total carotenoid contents were lowest in fresh fruit that were yellow or orange at harvest (Table 1). This agrees with reports for bell peppers, in which $\beta$-carotene was highest in brown and red fruit and lowest in orange- and yellow-fruited cultivars (Simonne et al., 1997). For red, ripe fruit in $1996, \beta$-carotene levels ranged from 12 to 166 $\mu \mathrm{g} \cdot \mathrm{g}^{-1}$ fresh weight, and carotenoid levels from 232 to $896 \mu \mathrm{g} \cdot \mathrm{g}^{-1}$. The range of values for $\beta$ carotene was similar in 1997 , but a wider range in total carotenoids for red fruit was

Table 1. $\beta$-Carotene, total carotenoid, and moisture content of fresh Capsicum fruit.

\begin{tabular}{|c|c|c|c|c|c|c|c|c|c|}
\hline \multirow[b]{2}{*}{ Species } & \multirow[b]{2}{*}{ Cultivar } & \multirow[b]{2}{*}{ Type } & \multicolumn{3}{|c|}{1996} & \multicolumn{3}{|c|}{1997} & \multirow[b]{2}{*}{ Color } \\
\hline & & & $\begin{array}{c}\beta \text {-carotene } \\
\left(\mu \mathrm{g} \cdot \mathrm{g}^{-1} \mathrm{FW}\right)\end{array}$ & $\begin{array}{l}\text { Carotenoids } \\
\left(\mu \mathrm{g} \cdot \mathrm{g}^{-1} \mathrm{FW}\right)\end{array}$ & $\begin{array}{c}\text { Moisture }^{2} \\
(\%)\end{array}$ & $\begin{array}{l}\beta \text {-carotene } \\
\left(\mu \mathrm{g} \cdot \mathrm{g}^{-1} \mathrm{FW}\right)\end{array}$ & $\begin{array}{l}\text { Carotenoids } \\
\left(\mu \mathrm{g} \cdot \mathrm{g}^{-1} \mathrm{FW}\right)\end{array}$ & $\begin{array}{c}\text { Moisture }^{2} \\
(\%)\end{array}$ & \\
\hline \multirow{14}{*}{ C. annuum } & Pulla & Guajilloy $^{y}$ & $99 \pm 25^{x}$ & $849 \pm 32$ & 81.3 & $136 \pm 7$ & $1173 \pm 49$ & 79.5 & Red \\
\hline & Ring-O-Fire & Cayenne & $56 \pm 2$ & $896 \pm 52$ & 81.6 & $82 \pm 14$ & $980 \pm 121$ & 84.1 & Red \\
\hline & NuMex Conquistador & New Mexican & $54 \pm 9$ & $474 \pm 65$ & 88.9 & $126 \pm 13$ & $893 \pm 63$ & 86.3 & Red \\
\hline & Thai Dragon & Asian hot & $51 \pm 9$ & $805 \pm 112$ & 80.1 & $65 \pm 4$ & $763 \pm 42$ & 79.9 & Red \\
\hline & Cherry Large Hot & Cherry & $43 \pm 7$ & $571 \pm 64$ & 95.6 & $37 \pm 4$ & $522 \pm 26$ & 89.8 & Red \\
\hline & Sante Fe Grande & Wax & $26 \pm 2$ & $344 \pm 24$ & 89.0 & $13 \pm 2$ & $143 \pm 28$ & 90.2 & Red \\
\hline & NuMex Joe E. Parker & New Mexican & $25 \pm 5$ & $353 \pm 42$ & 87.5 & $35 \pm 4$ & $348 \pm 36$ & 87.7 & Red \\
\hline & Biscayne & Cubanelle & $20 \pm 5$ & $235 \pm 53$ & 92.3 & $9 \pm 1$ & $94 \pm 12$ & 93.9 & Red \\
\hline & Chocolate Beauty & Bell & $20 \pm 2$ & $325 \pm 16$ & 92.0 & $6 \pm 1$ & $107 \pm 25$ & 92.5 & Brown \\
\hline & Pimiento & Pimiento & $19 \pm 3$ & $254 \pm 36$ & 91.0 & $20 \pm 5$ & $276 \pm 26$ & 91.0 & Red \\
\hline & Tangerine & Squash & $17 \pm 3$ & $151 \pm 17$ & 91.6 & $19 \pm 3$ & $162 \pm 21$ & 91.6 & Orange \\
\hline & Serrano & Serrano & $16 \pm 6$ & $266 \pm 30$ & 88.0 & $20 \pm 2$ & $433 \pm 76$ & 83.5 & Red \\
\hline & NuMex Sunset & New Mexican & $1 \pm 0.4$ & $29 \pm 3$ & 87.8 & $1 \pm 0.1$ & $67 \pm 30$ & 75.2 & Orange \\
\hline & Sante Fe Grande & Wax & $0.1 \pm 0.1$ & $1 \pm 0.2$ & 92.6 & ND & $4 \pm 3$ & 93.8 & Yellow \\
\hline \multirow[t]{3}{*}{ C. chinense } & Habanero Red & Habanero & $40 \pm 8$ & $446 \pm 41$ & 92.3 & $30 \pm 7$ & $348 \pm 25$ & 87.6 & Red \\
\hline & Datil & Datil & --- & --- & --- & $44 \pm 0.9$ & $276 \pm 8$ & 87.3 & Orange \\
\hline & Habanero Orange & Habanero & ND & $13 \pm 1$ & 89.1 & --- & -- & --- & Orange \\
\hline C. frutescens & Greenleaf Tabasco & Tabasco & $166 \pm 16$ & $849 \pm 87$ & 83.4 & $71 \pm 6$ & $562 \pm 107$ & 84.2 & Red \\
\hline
\end{tabular}

${ }^{\mathrm{z}}$ At harvest. $\mathrm{FW}=$ fresh weight.

${ }^{y}$ Fruit were deseeded, except for small-fruited tabasco, guajillo, Asian hot, datil, and serrano types.

${ }^{\mathrm{x}}$ Data are means for four replications $\pm \mathrm{SE} . \mathrm{ND}=$ not detectable. 
Table 2. $\beta$-Carotene, total carotenoid, and moisture content of dried Capsicum fruit.

\begin{tabular}{|c|c|c|c|c|c|c|c|c|c|}
\hline \multirow[b]{2}{*}{ Species } & \multirow[b]{2}{*}{ Cultivar } & \multirow[b]{2}{*}{ Type } & \multicolumn{3}{|c|}{1996} & \multicolumn{3}{|c|}{1997} & \multirow[b]{2}{*}{ Color } \\
\hline & & & $\begin{array}{r}\beta \text {-carotene } \\
\left(\mu g \cdot g^{-1} \mathrm{DW}\right)\end{array}$ & $\begin{array}{l}\text { Carotenoids } \\
\left(\mu \mathrm{g} \cdot \mathrm{g}^{-1} \mathrm{DW}\right)\end{array}$ & $\begin{array}{c}\text { Moisture }^{z} \\
(\%)\end{array}$ & $\begin{array}{c}\beta \text {-carotene } \\
\left(\mu \mathrm{g} \cdot \mathrm{g}^{-1} \mathrm{DW}\right)\end{array}$ & $\begin{array}{l}\text { Carotenoids } \\
\left(\mu g \cdot g^{-1} \mathrm{DW}\right)\end{array}$ & $\begin{array}{c}\text { Moisture }^{z} \\
(\%)\end{array}$ & \\
\hline \multirow[t]{31}{*}{ C. annuиm } & Bajio & Pasilla & $539 \pm 63^{y}$ & $6226 \pm 766$ & 78.7 & $1198 \pm 123$ & $10,121 \pm 1036$ & 83.3 & Brown \\
\hline & NuMex Conquistador & New Mexican & $669 \pm 74$ & $4682 \pm 392$ & 83.1 & $1141 \pm 129$ & $5597 \pm 1312$ & 82.1 & Red \\
\hline & NuMex RNaky & New Mexican & $633 \pm 57$ & $5011 \pm 558$ & 80.5 & --- & --- & --- & Red \\
\hline & NuMex Sweet & New Mexican & $606 \pm 49$ & $5227 \pm 583$ & 80.3 & $927 \pm 127$ & $6781 \pm 1047$ & 86.9 & Red \\
\hline & Ancho 101 & Ancho & $510 \pm 29$ & $4093 \pm 668$ & 83.0 & $785 \pm 70$ & $5830 \pm 846$ & 82.3 & Red \\
\hline & Biber Sivir & Turkish & $448 \pm 20$ & $3935 \pm 298$ & 81.5 & --- & --- & --- & Red \\
\hline & Sandia & New Mexican & $444 \pm 70$ & $4178 \pm 568$ & 74.8 & $559 \pm 41$ & $4359 \pm 157$ & 86.3 & Red \\
\hline & Merah & Asian hot & $428 \pm 43$ & $5130 \pm 762$ & 70.3 & $736 \pm 66$ & $5853 \pm 437$ & 84.9 & Red \\
\hline & Carliston & Wax & $390 \pm 32$ & $3881 \pm 608$ & 87.7 & $336 \pm 46$ & $3488 \pm 576$ & 55.0 & Red \\
\hline & Pulla & Guajillo & $369 \pm 52$ & $2998 \pm 317$ & 65.8 & $940 \pm 225$ & $6344 \pm 1376$ & 71.7 & Red \\
\hline & Guajillo & Guajillo & $343 \pm 54$ & $3721 \pm 547$ & 66.2 & $538 \pm 124$ & $4082 \pm 575$ & 85.7 & Red \\
\hline & Kalocsa & Wax & $328 \pm 18$ & $4659 \pm 297$ & 81.6 & $360 \pm 21$ & $3000 \pm 105$ & 56.7 & Red \\
\hline & Ring-O-Fire & Cayenne & $318 \pm 9$ & $3507 \pm 100$ & 66.8 & $446 \pm 26$ & $3990 \pm 212$ & 80.0 & Red \\
\hline & Ancho Mulato & Ancho & $317 \pm 41$ & $3070 \pm 326$ & 80.8 & $674 \pm 108$ & $4944 \pm 802$ & 85.4 & Brown \\
\hline & Tejaswini & Indian & $268 \pm 15$ & $3140 \pm 297$ & 57.5 & $448 \pm 87$ & $3388 \pm 555$ & 56.7 & Red \\
\hline & Large Thick Red & Cayenne & $217 \pm 22$ & $2642 \pm 363$ & 84.4 & $249 \pm 29$ & $3053 \pm 471$ & 88.2 & Red \\
\hline & Thai Dragon & Asian hot & $217 \pm 24$ & $2300 \pm 334$ & 75.6 & $304 \pm 29$ & $2976 \pm 187$ & 79.0 & Red \\
\hline & De Arbol & De arbol & $197 \pm 28$ & $2254 \pm 170$ & 54.2 & --- & --- & --- & Red \\
\hline & Santaka & Asian hot & $179 \pm 26$ & $2240 \pm 244$ & 56.3 & $225 \pm 12$ & $2398 \pm 145$ & 52.1 & Red \\
\hline & NuMex Mirasol & Mirasol & $173 \pm 21$ & $2256 \pm 226$ & 71.2 & $353 \pm 66$ & $2948 \pm 478$ & 72.4 & Red \\
\hline & Thai & Asian hot & $157 \pm 26$ & $1924 \pm 244$ & 57.1 & --- & --- & --- & Red \\
\hline & Tepin & Tepin & $88 \pm 14$ & $748 \pm 131$ & 55.2 & $169 \pm 28$ & $872 \pm 114$ & 55.0 & Red \\
\hline & Tarahumara & Tepin & $78 \pm 31$ & $845 \pm 227$ & 50.2 & --- & --- & --- & Red \\
\hline & NuMex Bailey Piquin & Piquin & $71 \pm 4$ & $780 \pm 43$ & 61.2 & $95 \pm 4$ & $963 \pm 80$ & 52.5 & Red \\
\hline & NuMex Sunburst & De arbol & $2 \pm 2$ & $111 \pm 12$ & 70.1 & $24 \pm 8$ & $187 \pm 25$ & 72.0 & Orange \\
\hline & Thai Hot & Asian hot & --- & --- & --- & $615 \pm 116$ & $3933 \pm 571$ & 79.9 & Red \\
\hline & Bulgaria & Wax & --- & --- & --- & $440 \pm 39$ & $3324 \pm 407$ & 77.0 & Red \\
\hline & Super Cayenne & Cayenne & --- & --- & --- & $435 \pm 39$ & $3891 \pm 405$ & 77.8 & Red \\
\hline & Flash & Asian hot & --- & --- & --- & $423 \pm 43$ & $3662 \pm 486$ & 70.3 & Red \\
\hline & Turkey & Turkish & --- & --- & --- & $320 \pm 54$ & $3073 \pm 567$ & 75.7 & Red \\
\hline & Spanish Paprika & Spanish & --- & --- & --- & $317 \pm 113$ & $2729 \pm 968$ & 88.9 & Red \\
\hline \multirow[t]{4}{*}{ C. baccatum } & Aji Escabeche & $\mathrm{Aji}$ & $565 \pm 94$ & $1986 \pm 433$ & 83.7 & $586 \pm 140$ & $1708 \pm 383$ & 76.7 & Orange \\
\hline & Aji Amarillo Mirasol & $\mathrm{Aji}$ & $455 \pm 22$ & $1476 \pm 61$ & 84.5 & --- & --- & --- & Red \\
\hline & Aji Amarillo & $\mathrm{Aji}$ & $34 \pm 4$ & $248 \pm 31$ & 83.3 & --- & --- & --- & Yellow \\
\hline & Aji Colorado & $\mathrm{Aji}$ & --- & --- & --- & $341 \pm 24$ & $2611 \pm 259$ & 72.4 & Red \\
\hline C. chacoense & Wild type & Tepin & --- & --- & --- & $137 \pm 19$ & $633 \pm 137$ & 52.3 & Red \\
\hline C. chinense & Aji Brown & $\mathrm{Aji}$ & $739 \pm 85$ & $5432 \pm 866$ & 84.3 & $285 \pm 55$ & $1991 \pm 304$ & 70.6 & Brown \\
\hline C. eximium & Wild type & Tepin & --- & --- & --- & $97 \pm 11$ & $649 \pm 119$ & 58.6 & Red \\
\hline \multirow[t]{2}{*}{ C. frutescens } & Tabasco & Tabasco & $351 \pm 47$ & $1484 \pm 306$ & 66.4 & $409 \pm 35$ & $1639 \pm 134$ & 75.6 & Red \\
\hline & Greenleaf Tabasco & Tabasco & $245 \pm 42$ & $1334 \pm 273$ & 79.1 & $437 \pm 19$ & $1999 \pm 77$ & 75.6 & Red \\
\hline
\end{tabular}

${ }^{\mathrm{z}}$ At harvest. All fruit were destemmed, but not deseeded, dried, and ground before analysis. DW = dry weight.

${ }^{y}$ Data are means for four replications \pm SE.

observed in 1997 (94 to $1173 \mu \mathrm{g} \cdot \mathrm{g}^{-1}$ fresh weight) (Table 1). Variation in pigment levels have been attributed to differences in cultivars, maturity, growing practices, climates, postharvest handling, and analytical methods (Mozafar, 1994).

Between 4.8 and $6.0 \mathrm{mg}$ of $\beta$-carotene would supply $100 \%$ of the RDA for vitamin A in adult females and males, respectively (National Research Council, 1989). Fresh fruit (100 g) of the cultivars Greenleaf Tabasco, Pulla, Guajillo, NuMex Conquistador, RingO-Fire, and Thai Dragon contained greater amounts of $\beta$-carotene than the RDA for vitamin A for the average adult (Table 1), assuming that the $\beta$-carotene was fully absorbed and converted to vitamin A in the body. Carrots (Daucus carota L.), sweet potatoes (Ipomoea batatas $\mathrm{L}$.), leafy green vegetables, and pumpkins (Cucurbita maxima Duch. ex Lam.) are other vegetables with high provitamin A activity (Bureau and Bushway, 1986). $\beta$-Carotene concentrations in sweet potatoes, carrots, beet (Beta vulgaris L.) greens and spinach (Spinacia oleracea L.) were $86,76,50$, and $43 \mu \mathrm{g} \cdot \mathrm{g}^{-1}$ fresh weight, respectively (Bureau and
Bushway, 1986). Red fruit of guajillo, tabasco, New Mexican, cayenne, and Asian hot entries tended to have concentrations of $\beta$-carotene (Table 1) equivalent to or higher than those of the four vegetables with highest values reported by Bureau and Bushway (1986). However, consumption of $100 \mathrm{~g}$ of these pungent chiles may be difficult for many people. One exception is 'NuMex Conquistador', which is a nonpungent cultivar.

$\beta$-Carotene concentrations in fresh, green fruit of bell, serrano, jalapeño, and New Mexican type chiles have ranged from 2 to 5,5 to 8 , 3 to 5 , and 2 to $5 \mu \mathrm{g} \cdot \mathrm{g}^{-1}$ fresh weight, respectively (Bureau and Bushway, 1986; Howard et al., 1994; Mejia et al., 1988; Simonne et al., 1997). In our study, $\beta$-carotene content of red bell peppers ('California Wonder') averaged $11 \mu \mathrm{g} \cdot \mathrm{g}^{-1}$ fresh weight, and red, ripe fruit of serrano, jalapeño ('Mitla'), and New Mexican type chiles ('NuMex Joe E. Parker') contained 18,22 , and $30 \mu \mathrm{g} \cdot \mathrm{g}^{-1}$ fresh weight, respectively, when averaged over 2 years. Howard et al. (1994) reported $\beta$-carotene concentrations in red, ripe fruit of bell, serrano, jalapeño, and New Mexican type cultivars as high as 14, 13,
26 , and $28 \mu \mathrm{g} \cdot \mathrm{g}^{-1}$ fresh weight, respectively. Therefore, the provitamin A value of ripe fruit can be 3 to 15 times as high as that of green fruit, depending on fruit type, cultivar, and growing conditions.

For dried Capsicum entries, New Mexican, aji, pasilla, ancho, and guajillo types had the highest levels of $\beta$-carotene (Table 2). About $10 \mathrm{~g}$ of these dried fruit would meet or exceed the RDA for vitamin A based on $\beta$-carotene alone. In 1996, $\beta$-carotene levels among the Capsicum cultivars surveyed ranged from 2 to $739 \mu \mathrm{g} \cdot \mathrm{g}^{-1}$ dry weight, and carotenoid levels from 111 to $6226 \mu \mathrm{g} \cdot \mathrm{g}^{-1}$ (Table 2). Values were higher in 1997, and ranged from 24 to $1198 \mu \mathrm{g} \cdot \mathrm{g}^{-1}$ dry weight for $\beta$-carotene and from 187 to $10,121 \mu \mathrm{g} \cdot \mathrm{g}^{-1}$ for total carotenoids (Table 2).

The total carotenoid levels of dried fruit are relevant for breeding high pigment paprika and chiles (C. annuum, New Mexican type) for the food industry. Carotenoids are added either as dehydrated, ground fruit or carotenoid extracts (oleoresin) to a range of food products, cosmetics, and pharmaceuticals as natural colorants. New Mexico State Univ. 
paprika cultivars ('NuMex Conquistador' and 'NuMex Sweet') were among the six dried entries with the highest $\beta$-carotene and total carotenoid content in both years. Thus, genes for high pigment content exist within the germplasm used in the breeding program. However, a pasilla type ('Bajio', C. annuиm) had the highest total carotenoid content among the dried entries in both years. Also, reports by Levy et al. (1995) of a breeding line with total carotenoids of $16,600 \mu \mathrm{g} \cdot \mathrm{g}^{-1}$ dry weight shows that further improvements for carotenoid content are possible. Fruits of other $C$. апnиит lines contained from 3250 to $10,710 \mu \mathrm{g}$ total carotenoids, and from 254 to $840 \mu \mathrm{g} \beta$-carotene/g dry weight (Levy et al., 1995), which were similar to our results. We have hybridized 'Bajio' pasilla with 'NuMex Conquistador' and advanced breeding lines in hopes of further enhancing total carotenoids in New Mexican-type chiles.

Consumers should be educated about the benefits of including fresh and dried red Capsicum fruit in the diet. Chile fruit are nutritionally balanced with respect to the antioxidant vitamins $\mathrm{A}, \mathrm{C}$, and $\mathrm{E}$. Red chiles contain at least three to four times more vitamin A, C, and $\mathrm{E}$ than do green fruit (Osuna-Garcia et al. 1998). Also, if the high levels of total carotenoids are considered, the contribution of red chiles to overall human health may be substantial. The antioxidant properties of carotenoids such as capsanthin and capsorubin have not been fully studied, but may be important in preventing cancer and cardiovascular disease (Machlin, 1995).

\section{Literature Cited}

Bosland, P.W. 1994. Chiles: History, cultivation, and uses, p. 487-500. In: G. Charalambous (ed.). Herbs, spices, and edible fungi. Elsevier Sci. Publ., Amsterdam.

Bureau, J.L. and R.J. Bushway. 1986. HPLC determination of carotenoids in fruits and vegetables in the United States. J. Food Sci. 51:128-130.

Bushway, R.J. and A.M. Wilson. 1982. Determination of $\alpha$ - and $\beta$-carotene in fruit and vegetables by high performance liquid chromatography. J. Can. Inst. Food Sci. Tech. 15:165-169.

Byers, T. and G. Perry. 1992. Dietary carotenes, vitamin $C$, and vitamin $\mathrm{E}$ as protective antioxidants in human cancers. Annu. Rev. Nutr. 12:139-159.

Food and Agriculture Organization. 1995. 1994 FAO Production Yrbk. Vol. 46. FAO, Rome, Italy.

Gregory, G.K., T. Chen, and T. Philip. 1987. Quantitative analysis of carotenoids and carotenoid esters in fruits by HPLC: Red bell peppers. J. Food Sci. 52:1071-1073.

Haytowitz, D. and R.H. Matthews. 1984. Composition of foods: Vegetables and vegetable products. U.S. Dept. Agr. Hdbk. 8-11. Washington, D.C.

Howard, L.R., R.T. Smith, A.B. Wagner, B. Villalon, and E.E. Burns. 1994. Provitamin A and ascorbic acid content of fresh pepper cultivars ( Capsicum annuum) and processed jalapeños. J. Food Sci. 59:362-365.

Isidoro, E., D.J. Cotter, and G.M. Southward. 1990. A comparison of color loss of red chile pepper pods on or off the plant and during storage as powder. HortScience 25:954-955.

Ittah, Y., J. Kanner, and R. Granit. 1993. Hydrolysis study of carotenoid pigments of paprika (Capsicum annuum $\mathrm{L}$. variety Lehava) by HPLC/photodiode array detection. J. Agr. Food Chem. 41:899-901

Kanner, J., S. Harel, D. Palevitch, and I. Ben-Gera. 1977. Colour retention in sweet red paprika (Capsicum annuum L.) powder as affected by moisture contents and ripening stage. J. Food Technol. 12:59-64.

Kritchevsky, S.B. 1999. $\beta$-carotene, carotenoids and the prevention of coronary heart disease. $\mathrm{J}$. Nutr. 129:5-8.
Levy, A., S. Harel, D. Palevitch, B. Akiri, E. Menagem, and J. Kanner. 1995. Carotenoid pigments and $\beta$-carotene in paprika fruits (Capsicum spp.) with different genotypes. J. Agr. Food Chem. 43:362-366.

Machlin, L.J. 1995. Critical assessment of the epidemiological data concerning the impact of antioxidant nutrients on cancer and cardiovascular disease. Crit. Rev. Food Sci. Nutr. 35:41-50.

Mejia, L., E. Hudson, E. Gonzalez de Mejia, and F. Vazquez. 1988. Carotenoid content and vitamin A activity of some common cultivars of Mexican peppers (Capsicum annuum) as determined by HPLC. J. Food Sci. 53:1448-1451.

Mozafar, A. 1994. Plant vitamins: Agronomic, physiological and nutritional aspects. CRC Press, Boca Raton, Fla.

National Research Council (NRC), Food and Dietary Board. 1989. Recommended dietary allowances. Natl. Acad. Sci., Washington, D.C.

Osuna-Garcia, J.A., M.M. Wall, and C.A. Waddell. 1998. Endogenous levels of tocopherols and ascorbic acid during fruit ripening of New Mexican-type chile (Capsicum annuum L.) cultivars. J. Agr. Food Chem. 46:5093-5096.

Palevitch, D., S. Harel, J. Kanner, and I. Ben-Gera. 1975. Effects of pre-harvest dehydration on the composition of once-over harvested sweet paprika. Scientia Hort. 3:143-148.

Simonne, A.H., E.H. Simonne, R.R. Eitenmiller, H.A. Mills, and N.R. Green. 1997. Ascorbic acid and provitamin A contents in unusually colored bell peppers (Capsicum annиит L.). J. Food Comp. Anal. 10:299-311.

Sommer, A. 1989. New imperatives for an old vitamin (A). J. Nutr. 119:96-100.

Valencia, M.E., R.P. Jardines, E. Noriega, R. Cruz, I. Grijalva, and C. Peña. 1983. The use of 24 hour recall data from nutrition surveys to determine food preference, availability and food consumption baskets in populations. Nutr. Rp. Intl. 28:815.

World Bank. 1993. World development report 1993: Investing in health. Oxford Univ. Press, New York. 